\title{
SQUATTER SETTLEMENT: COSTS AND CONTRIBUTING FACTORS IN JIMMA TOWN, OROMIA NATIONAL REGIONAL STATE, ETHIOPIA
}

\author{
NEGA ABERA AKIRSO \\ Department of Sociology, College of Social Science and Humanities, Jimma University, Ethiopia \\ (c) 2021 Nega Abera Akirso
}

This is an open access article distributed under the Creative Commons Attribution-Non Commercial-No Derivs license (http://creativecommons.org/licenses/by-nc-nd/3.0/)

DOI: $10.1515 /$ eras-2021-0002

\begin{abstract}
Urbanization and urban growth are considered as a modern way of life which manifests economic growth and development in many countries. On the other hand, it yields a number of evils, especially unplanned (squatter) settlement. The study conducted on the area of squatter settlement in Jimma town is aimed to explore the socioeconomic factors contributing for squatter settlement and its effect on social, economic and institutional conditions of settler and development of the town. The study was guided by qualitative research approach and employed cross-sectional and phenomenological design in which primary data required for the analysis was collected through key informant interview, focus group discussion, non-participant observation as well as secondary data from document and analyzed by thematic analysis. The findings of this study revealed that, the root cause identified for squatter settlement is shortage of residential house and its consequential high price of house rent, the need of holding large plot of land and inefficient land administration system. Other findings indicated that squatter settlement incur costs on both the government and the squatter. Squatter settlement creates fear and dearth of confidence on the land they hold illegally, poor infrastructure due to lack of government interventions and low social service delivery, and social distress within the community. The study also found out that squatting displaces the host ex-farmers from their farmland and leads to consequent poverty and livelihood disasters. It is recommended that, political will in accessing residential land and financial commitment of the government is required. Active participation of the public and abiding legal procedures in accessing residential land is vital.
\end{abstract}

\section{Keywords}

Informal, misery, squatter, settlement, slum

\section{Background of the study}

Urbanization is an inevitable phenomenon across the board and is widely accepted all over the world, especially in developing countries. In developed countries of western regions, urbanization has been a result of industrialization and has been associated with economic advancement. By contrast, in developing countries of Latin America, Africa and Asia, urbanization has occurred as a result of high natural urban population increase due to huge rural-to-urban migration.

Evidently, most cities in developing countries are expanding horizontally than vertically and the ever-increasing population is moving to unplanned settlements on the peripheries at the expense of agricultural lands and areas of natural beauty (Desalew, 2015). Such unplanned settlements produced new peripheral spaces on the margins of national states and of urban territories. Among these sites, squatter settlement is the commonly known area 
of settlement surrounding the urban center (Toffin, 2010). These rapid rates of urbanization and unintended expansion of cities in developing countries have resulted in various negative effects (Elfarnouk, 2015) on the path of city development and lives of both urban and periurban dwellers.

Informal settlements (frequently referred to as squatter settlements) are dense and out of plan settlements comprising communities housed in self-constructed shelters under conditions of informal land tenure. Informal settlements are common features in developing countries and are typically conceived as the product of an urgent need for shelter to the urban poor (Desalew, 2015; UN-Habitat, 2015). Moreover, squatter settlement is not only the result of lack of urban houses for the poor, but also it is taken as a sort of business option for some group of people.

Mostly it is believed that the manifestation of squatter settlements in developing countries is widely due to a failure of how to deal with the phenomenon of rapid urbanization. The practice of informal settlement takes place and increases its intensity when land administration and planning fail to address the needs of the whole community (Adiukwu, 2014; Hurskainen, 2004; Mohammed \& Mohammed, 2006) in the urban area. As a result of illegality and lack of formality, areas established by squatter settlement usually would not have access to public utilities and social services.

According to UN-Habitat report in 2015, in Africa, over half of the urban population (61.7\%) lives in informal settlement area and by 2050, Africa's urban dwellers are projected to have increased from 400 million to 1.2 billion. Urban centers in Ethiopia are characterized by massive housing problem and around $70-90 \%$ of urban population are living in substandard housing, low economic activities, and inadequate upgrading with fast growth of population of $4 \%$ per annum (UN-Habitat, 2018). Such fast growing of the town and population creates shortage of residential homes and increasing house rents in the urban dwellers. Following this, informal purchasing of land plots and grabbing open space from the periphery for the construction of residential homes (squatter settlement) are considered as a solution for the housing problem of dwellers (Degu, Melesse \&Jafari, 2015; Mostafa, 2009).

\section{Statement of the problem}

Squatter settlement is a fashionable phenomenon in urban areas of Ethiopia at the expense of outskirt ex-farmers' land. According to Desalew (2005), horizontal sprawl and expansion of urban center in Ethiopia are characterized by mass displacement of the outskirt ex-farmers from their farmland and consequent fast expansion of squatter settlement. The experience of Jimma town expansion is the same as that of other town in the country. This assumption is confirmed by Tamrats' (2016) study and based on his finding, outward expansion of urban settlements and institutions are observed in all corners of Jimma town. Moreover, based on Jimma town Municipality (2018) assessment report, among the seventeen kebeles found in the town, in eight kebele, the phenomenon of squatting is trendy activity, implying that to a great extent the problem is widening in the town. The weak urban house affordability pushes inhabitants to the engagement of squatter settlement as a normal phenomenon, and consequently claimed as a source of various predicaments for the town administration.

According to Tendayi (2011) cited in Degu et.al (2015), the causes for development and expansion of squatter settlements in urban centers of Ethiopia seems the same but slightly vary from place to place. According to their study, in Addis Ababa the main cause for squatter is high-priced land values for the poor; in Adama city, limited capacity of local authorities to develop and deliver land to the poor, inefficient land delivery process and poor land administration. The same study found out that, in Bahir Dar city, unaffordable standards of 
urban land, low household income and inability of the poor to save were identified as the leading causes; where as in Jimma city the causal factors for the expansion of squatter settlement are not investigated in detail but minor studies show that high costs of building materials, poverty, corruption and generally inefficient land administration process are conceived as causal factors for squatter settlement (Degu et al., 2015).

The response options to the emerging informal settlement process as from state and local authorities have taken a variety of forms. These have often ranged from accommodation and co-optation to coercion. Regardless of the response option adopted and implemented in urban areas, the resultant scenario has often taken two forms. On one hand it has resulted in isolation and resistance and on the other it has resulted in partnerships, cooperation and mutual problem solving. According to Tandayi (2011), the response to squatter settlement taken by the local government in majority of Ethiopian towns are both coercive and cooptation. Formalization of illegal settlements through validation of security of tenure as well as a series of demolitions in the past have been tried. However, demolition of illegal structures is not done consistently, and affected families tend to reassemble and start squatting all over again. Eviction in some cases led to social and political strife between victims and the local authorities. On the contrary, regularization of squatter settlements attracted more informal settlers in the town; hence, it gives chances for squatters to legalize informally owned land.

Even though, the practices, causes and costs of squatter settlement are immense and vary from place to place and overtime, as to the knowledge of my understanding, the issue of squatter settlement was not well investigated in Jimma town in contrast to the expansion of squatter settlement. Having this general understanding, the researcher is motivated to explore the nature of squatter settlement, its cause and costs on the dwellers and local government in Jimma town.

\section{Objective of the study}

The main objective of this study is to explore the contributing factors of squatter settlement in Jimma town and its effect on social, economic, and institutional conditions of the settler and improvement of the town.

To meet the general objective, this study mainly focused on the following specific objectives:

1. To examine the practices of squatter settlement in the study area,

2. To scrutinize contributing factors for squatter settlement in the study area

3. To explore the costs of squatter settlement on the squatter and urban upgrading.

\section{Description of the study area}

Jimma is an old aged town in the South Western Ethiopia located in Oromia National Regional State, $346 \mathrm{Km}$ away from Addis Ababa. The present town of Jimma was developed surrounding Awetu River by the Italian colonial regime in 1930s and served as a center of market for the collection, organization, and export of a cash crop in the region. Jimma town evolved as a hometown of the Kingdom of Abba Jifar I (1830-1855), with relatively homogenous society and culture. It gradually developed to a place of residence for a diverse and increasingly multi-ethnic population as Yonas explained; both the urbanity and the urbanization of Jimma can be explained by the story of coffee production and marketing (2016).

Based on the 2013 Census projection by the Central Statistical Agency of Ethiopia (CSA), the total population of Jimma town in 2019 is 195,228, of whom 97,359 are men and 97,969 are women. With an area of 50.52 square kilometers Jimma has a population density 
of 3,864.4 per square kilometer. A total of 52,149 households were counted in the town, which results in an average of 3.74 persons to a household, and 48,625 housing units. According to Jimma town administration office (2019), administratively the town administration is classified in to 17 kebele, of which, 13 kebele are inner city kebeles and the rest 4 kebele outskirt kebele.

Currently, population growth in Jimma town is increasing at alarming rate due natural growth and rural to urban migration. Hence, Jimma town is the center of business for southwestern region of the country. This unplanned growth of population in the town manifested high demand of urban house for residential purpose and yielded different problems that are related to urban land management.

\section{Research methodology}

This study was conducted in purposively selected kebele of Jimma town, Oromia Regional State, based on the level and prevalence of squatter settlement practices. To meet the stated objectives, the study was guided by a qualitative research approach. Hence, to collect necessary data from the scratch and to gain deep information about the study issue, qualitative approach is better than quantitative. Regarding the study design, this study employed phenomenological study design under cross-section time frame. The necessary data required for this study was gained from both primary and secondary sources. The primary data was collected from key informants and observation through interview guide and checklists, while secondary data was collected through reviewing written documents, by reviewing literature and other studies. The sources of primary data were Jimma town municipality officials and experts, kebele leaders as well as the squatters. The necessary data was collected from informants until data saturation point reached. Personal observations were made in the selected squatter settlement sites to understand the animate condition in the setting. Finally, data were summarized, analyzed, interpreted and presented thematically in verbal form as per the specific objectives.

\section{Results and discussion}

\section{The extent of squatter settlement in the study area}

Primary data collected from key informant interview of municipality officials, and kebele leaders indicated that the extent of squatter settlement in Jimma town is high, in that it is practiced in eight kebeles out of seventeen. This implies that almost 50\% of the town kebeles are familiar with the squatter settlement. As indicated by municipality key informants, they define squatter settlement as 'an illegal holding of land and construction of house in the outskirt areas of the town, without any urban plan and permission of the concerned body'. The phenomenon is characterized by its unauthorized land holding and construction, absence of infrastructure and basic social service and substandard housing. This shows that the working definition of squatter settlement and its characteristics equates with the definition given by Daniel in 2006 and UN-Habitat 2015, as a violation of formal rules about property rights, zoning types and quality of construction. But UN-habitat definition considers such type of urbanity as a 'slum'.

Squatter settlement in Jimma town is manifested in the form of land occupation and land development as to key informants. Accordingly, a key informant from municipality elaborated the insights that:

“......grabbing government acquired land and buying agricultural lands at the fringes of urban from farmers are the common practices 
in the town. Government owned lands planned to multi-services are one of an area of land grabbing by individuals in the town. And also, due to fear of urban expansion and consequent expropriation, farmers who owned large plots of land for agricultural purpose, transfer parcel of their land to the third party, either by informal selling or via in the form of gift".

According to kebele leaders, the process of construction of squatter house is undertaking over night by using old tin roof to make it as an old house. Due to this, in Jimma town the price of old tin is much higher than that of new one according to kebele officials. They confirmed that the selling price of a single new roof tin in Jimma town is 150 ETB, while the same brand old tins' price accounts from 175-200 ETB in the town.

\section{Participants in squatter settlement}

Squatting, as a phenomenon of grabbing lands for residential, is claimed as the act of land less and lower income people in the area. Regarding the group of people engaging in squatter settlement as described by key informants from government office that, it is impossible to clearly demarcate participants by their economic or social status, hence, from the very lower to higher income groups are participating in the phenomenon, but the purpose is different. A key informant from kebele administration illustrated the above idea by saying that:

"In our kebele, persons who participated and owned lands illegally
are both who have residential house in the town as well as homeless
and landless people where their income is lower. He corroborated
that squatter settlement is a matter of land grabbing than only
problem induced solution for urban residents. Virtually, people
participating in squatter settlements are various in socio-economic
statuses. Squatter settlement is also one of the business and profit-
making area for some groups of individuals. They buy and sell parcel
of land in a continuous exchange".

The above data show that, land, especially urban land, as a scarce resource, is demanded by different groups of people irrespective of the income level of competent groups. Land in urban areas has lots of competing interests.

\section{Costs of squatter settlement on the squatted and local government}

Data gained from primary sources indicated that squatter settlement incurred costs on both the government and the squatter/ resident. According to informants from one of squatter settlement kebele; squatter settlement creates fear and dearth of confidence on the land they hold illegally, leads to poor infrastructure and low social service delivery. Another informant from other corridors of squatter settlement verified that squatting creates social distress within the community by creating uncertainty in their stay and leads to economic crises when demolished. Squatter settlement also displaces the host ex-farmers from their farmland and consequent poverty and livelihood disasters as reported by the key informant form the host 
community. The social disintegration of settlers from their place of origin like $\operatorname{Idir}^{l}, E k u b^{2}$ and family breakdown are another negative impacts of squatter settlement as indicated by key informants. A key informant from Jimma municipality illustrated that informality leads government to lose income that should be gained from both annual tax and land lease, creates difficulty to upgrade infrastructure and provide social service, hence, the house is constructed out of or without urban plan in a congested manner. This result confirms the argument of Huskanien (2004) in that, due to constant fear of eviction the development of urban and investment ought to be hindered. In general, unplanned urban growth leads to long run and complicated problems unless it is managed prior to the phenomenon happening.

\section{Contributing factors for squatter settlement}

The root causes for squatter settlement in Jimma town are basically two as indicated by the key informants. The first one is shortage of residential house which fulfills the demand of urban people and its consequential high price of house rent. The second causal factor is the need of holding large plot of land for the purpose of either to have an open space surrounding the residential area or to sell it later for getting much profit. These conditions, according to an informant from one squatter settlement kebele, are initiated from the weak supply of urban land to the urban dwellers for residential houses. He also added that, the practice of land sale by land speculators as a means of making profit heightens the expansion of squatter settlement. Another key informant from Jimma town municipality justified the causal factors that, less government control of open spaces and lack of a comprehensive legal response towards the problem of squatting are identified as factors that have contributed to the emergence and spread of squatter settlements in Jimma town. These findings corroborate with the finding of the study conducted by Degu and his colleagues in 2015 in Burayu town and UN-Habitat report of 2015, in that the practice of squatter settlement is not only the result of poverty and low income of squatter household, however, cumbersome procedures, very poor performance of land development and management agency to deliver the land to the applicants and inefficient land administration process are the pressing factors for the growing rate of squatter settlement.

\section{Government's intervention in squatter settlement area}

Even though the problems are wide and touch a large group of people in the town, key informants from kebele administration forwarded that some measures were taken to tackle the problem. According to the key informants from the municipality and kebele leaders, formalizing the squatter settlers who were settled before 2012 was done by the help of aerial photo. By these actions, they reported that a significant number of squatter settlers was formalized in one of the kebele "Mendera Qochi", as indicated by the kebele leader. Demolishing illegal houses which were built after 2012 was the other side of responses taken by the local government on the squatter settlement. However, measures taken by the government were and are full of hindrances as pointed out by the key informants. They elaborated that, the process of formalization of squatter settlements permits only squatters who registered prior to 2012 and legalize only $200 \mathrm{~m}^{2}$ for each settler. Restriction on the specified size leads grievance and geared to a conflict between squatter and government.

\footnotetext{
${ }^{1}$ A form of informal social institution serves as a financial institution by providing credit service to the group member and labor support in time of crises.

${ }^{2}$ An informal social institution undertaking the saving of money.
} 
The above data gained from primary sources show that the response of government towards squatter settlement is focused on both formalization and demolition. Demolition, employed by the government as a response to squatter settlement, is conceived by the victims as a crisis and an irresponsible measure. Hence, they claim that the practice of squatter settlement in the town is not an occasion, but seemingly continued from the past. The government officials overlooked the act and lastly used forceful action. In general, the response of government can be categorized under laissez-faire, co-optation and coercion which were best clarified by Tendayi (2011). In sum the finding clearly depicts that the overall situation of squatter settlement is the result of land policy and administration failure, hence weak land management and information created an open space and better environment for informality in urban housing in Jimma town.

\section{Conclusions}

Rapid urbanization and inadequate capacity to cope with the housing needs of people in urban areas have contributed to the development of informal settlements. Informality (squatter settlement) is triggered by different factors. There are three views regarding the root cause of squatter settlement in Jimma town based on the findings. The first line of view considered by the town government is that most of the squatter settlement found in Jimma town are not 'poverty driven' in its character. But people having better income are squatting to the periphery to access large plot of land for recreation. The ex-farmer who live surrounding the town transfer parcel of their land to the third party due to fear of eviction from their land by municipality either by informal marketing or distributing their farm lands to their family and relatives to construct informal houses.

The other view generally perceives that informal settlement is driven by poverty and housing problem. The assumption is that the land value in a formal way is higher to access and a full of lengthy bureaucracy, as well as time taking. On the other hand, the house rent value increases at higher speed. To escape from this problem, the lower income groups are choosing squatter as a solution. The third view is that the cause for squatter settlement is poor land administration system. The inability to afford sufficient land for the dwellers, poor performance of land development and management, the absence of clearly demarcated land ownership right created an open space for squatter settlement. The contributing factors for squatter settlement are multi-faceted but can be managed under the poor land administration system that unable to access residential land and control informal land marketing.

Measures dealt with challenges posed by informality in Jimma town can be also categorized in to three. The first category is laissez-fair - leaving the phenomenon as it is. Such measures were also implemented in the town at the early stage of squatting. Uncontrolled expansion of squatter settlement on the open space and urban fringe ex-farmers land were the result of such measure. The second measure is coercion, by using bulldozers or law in demolishing and relocating the squatter. It was implemented in town, but created a political strife and economic damage. The third category is co-optation. It is a form of upgrading the squatter settlement by ensuring security of tenure for the property owner in the settlement. Such measure removes the fear of perpetual ejection and creates an interest to invest in the improvement of the house and their environment. This measure was also implemented by the government, but the process of implementation is bounded by law and raised fairness issue.

In general, the response to the problem was not clearly identified. The entire measures were taken even at the same time and because of these the extent of squatter settlements in the town are growing rather declining.

The socio-cultural misfortune of settlers in the new setting is another concealed but 
tensioned aspect of squatter settlement. The absence of community based institutions (Iddir and Ekub) and formal work setting weaken the interaction of residents in the community.

\section{Recommendations}

The appropriate handling of squatting activities requires a lot of political will, proper urban land administration and system and financial commitment of the government, as well as active participation of the public.

- $\quad$ Political will is essential in order to embark on land reform that will not put the urban poor at a disadvantageous position with regard to access to residential land.

- Participatory upgrading of squatter settlement is vital. Virtually, government cannot fulfill the development demanded by citizens in all areas as soon as possible, so that communities' involvement in squatter upgrading should be recognized and mobilized.

- Inefficiency of urban authorities, along with poor land management practices and inadequate urban planning schemes should be solved by creating multi-sectorial and comprehensive urban planning approach with clear mandate analysis.

- The right of citizens in accessing a residential area should be respected. To do that, the approach of leasing urban land should be seen critically because the current practices of land lease favor free competition, which excludes economically poor from the game; hence, their purchasing power is lower than that of the rich.

- $\quad$ Fair compensation to the periphery rural land by municipality can minimize illegal market of land surrounding urban outskirt.

- $\quad$ The response to already existing squatter should be stick to co-optation, hence it encourages collaborative effort in seeking solutions to the problem.

- The government should intervene in the enhancement of infrastructure and social service delivery institutions without marginalization. Hence, it can create a social harmony among the residents and ignite a way to form both formal and informal social institutions in their physical setting.

\section{REFERENCES}

Adiukwu O. Fidelis (2014). Prospects and challenges of informal settlement and urban upgrading in Abuja. IJISR, 11(2): 402-426.

CSA (2013). Population projection of Ethiopia for all regions at wereda level from 2014-2017

Daniel, Lirebo (2006). Housing in Urban context: informal settlement in Addis Ababa, Ethiopia, Addis Ababa University

Degu Bekele, Melesse Asfaw and S.S.A Jafari (2015). Causes and Remedy of Squatting in Burayu Town, Ethiopia, Developing Country Studies, 4(11): 10-18

Desalew, Berhane (2015). Squatter settlement and its impact on urban amenities of Tilil town, Awi Zone, Ethiopia, MA thesis in Geography and Environmental studies, Addis Ababa University

Endalemaw, Sewinet (2014). Growth of slum, problems, and solutions: the case Kebele 07, Dire Dawa City, Ethiopia; MA thesis in Georaphy and Environmental study. Haramaya University

Hurskainen, Pekka (2004). The informal settlement of Voi, Journal of field research to Kenya, 40(6): 64-78

Minwuyelet, Melesse (2005). Squatter settlement, and policy implications in Addis Ababa: the case of KolfeKeranio sub-city; working paper on population and land use change in central Ethiopia number 2, Addis Ababa University

Mohammed Ali and Muhammed Sulaiman (2006). The cause and consequence of informal settlement in Zanzibar, XXIII FIG congress, 1-17

Mostafa, Talshi (2009). Informal settlement and sustainable urban development case study: Metropolis on Mashhad in Northeastern Iran. Journal of World applied science, 7(10): 1235-1238

Nouri, Elfarnouk (2015). Squatter settlement in Tripoli, Libya: Assessing, monitoring and analyzing the Incidence and prevalence of urban squatter areas in the peri-urban fringe, Libya, Kansas University

Sietchiping, Remy (2005). Prospective slum policies: conceptualization and Implementation of proposed 
informal settlement growth model. SAGE, Melbourne University

Tendayi, Gondo (2011). Housing informality in expanding Ethiopia cities: Moving beyond the 'the new formal', REAL CORP, Tagungs band

Toffin, Gerard (2010). Urban fringe: squatter and slum settlement in the Kathmandu valley (Nepal). CNAS Journal, 2792: 158-168

UN-Habitat (2015). Informal settlement: Habitat III issue paper, New York

Yonas, Seifu (2016). Modern education in Jimma town, south west Ethiopia: A historical survey, 1932-1991. IJSR, 5(10): 1088-10 